\title{
CHRISTIANITY FACING THE AGEING OF GLOBAL POPULATION
}

\author{
AnNa SANECKa \\ Faculty of Theology, The Christian Theological Academy, \\ ul. Miodowa 21 c, Warsaw, Poland. \\ E-mail address: anna.sanecka@gmail.com
}

\begin{abstract}
The ageing population is a great challenge for the whole world including churches, Christian communities, Christian families and the so-called "Christian countries". The respect and support for elderly people is almost a common rule of social life in developed countries regardless of religious views. But in the Christian world this obligation has very strong religious justification - obligation enshrined in the Commandments of Old (the fourth/fifth Commandment) and New (the second one of The Greatest Commandments of Love) Testaments. Therefore between the Christianity - understood as a set of different communities sharing their beliefs in Jesus Christ - and aging population there are many very different connections including among others: honour and respect, privilege, obligations, giving - receiving relations, duty, charity, solidarity, dependency. They are present both in the teaching and the practice of different Christian communities starting with Churches, through NGOs and Christian societies, ending with Christian families. The paper shows some of these connections. It also tries - based on a case of Poland - to answer the question whether the Christianity is ready to face the aging of global population.

Keywords: Christianity, Commandments, obligation, honour, respect, help, support, charity, old age, elderly peoples, parents, churches, Christian communities, teaching, attitude
\end{abstract}

\section{PREFACE}

While the global population is getting older it demands from different outlooks, religions and ideologies to reconsider their attitudes towards this problem. But it seems that the aging of global population is a real problem for the Christianity itself and all the Christian denominations. The religion was born in the times when people rarely lived to their eighties or nineties. But nowadays while the circumstances and demography are changing, Christianity needs to face the problem of ageing, both in its teaching and practical attitude towards a growing population of old people. Concerning the aging of global population Małgorzata Strzelec writes that "this phenomena is a demanding challenge for old people themselves, but also their closest families, local societies and whole society" (Strzelec, 2008, p. 175).

In 2014 The Global AgeWatch Index report was published for the second time. "The Global AgeWatch Index is the only global index to rank countries according 
to the social and economic wellbeing of older people." (The Global AgeWatch Index2014, http:/ / www.helpage.org/global-agewatch, p. 2) In 2014 it ranked the situation of older people in 96 countries. As Professor Sir Richard Jolly from the Institute of Development Studies at University of Sussex underlined in the preface to the report:

"People do not stop developing when they reach sixty or seventy or eighty. Our older years should be as much a time to expand our horizons as our earlier years. Supporting older people will help to create a world where all feel confident to live with dignity and security" (Jolly, 2014).

The Index states that "Apart from Japan (9), all the top 10 countries are again ${ }^{13}$ in Western Europe, North America and Australasia" (The Global AgeWatch Index2014, p. 8). It means that 9 of the top 10 countries belong to the world of Christian civilisation ${ }^{14}$. The last country in ranking of wellbeing of older people is Afghanistan ${ }^{15}$. It of course does not mean that we can say that the Christianity impacts somehow the better situation of elderly people, as The Global AgeWatch Index does not consider the religious data in its report, but in this article we would try to have a look at elderly people's situation in Christian countries as they were 9 out of 10 in top 10 ranked countries ${ }^{16}$.

As a Polish Roman Catholic bishop, Kazimierz Romaniuk, wrote:

"the level of society's humanistic culture depends on the number of orphans', seniors' and incurably sick people's houses existing in such a country. There is a big role to be executed in these terms not only by governmental social security institutions but also by all kinds of sisterhoods which feel they are called by God Himself to care for lonely and old people. Abandonment of lonely, forlorn and old people is condemnation of society. Such a situation inculpates reprehensibly firstly the members of the closer family, who are still alive, sometimes even one's children, but also is a condemnation of the local authorities and all the people being a part of a society" (Romaniuk, 1993, p. 82).

In this paper we will try to look at the phenomena of old age from the Christian point of view. We will try to investigate whether the Christianity itself and all Christian churches and religious communities as well as so called Christian

13 The first Global AgeWatch Index was prepared in 2013.

14 According to Encyclopaedia Britannica there is no official, dominant religion in Japan, but the two biggest religious groups are Buddhism and Shinto. (http://www.britannica.com/place/Japan/ Religion)

15 The official name of the country is Islamic Republic of Afghanistan. And the official religion is Islam. (http://www.britannica.com/place/Afghanistan)

16 By a "Christian country" we will understand a country where the dominant religion is one belonging to Roman Catholic, Orthodox or one of the Protestant denominations, even if there is no official religion in such a country. From this point of view 9 of the top 10 (excluding Japan) countries from Global AgeWatch are Christian: Norway - Evangelical Lutheran, Sweden - Evangelical Lutheran Church of Sweden; Switzerland - Roman Catholic and Protestant; Canada - Roman Catholic and Protestant (United Church of Canada, the Anglican Church of Canada, and the Lutheran church), Germany - Roman Catholic and Protestant; Netherlands - Roman Catholic, Protestant and the nonreligious; Iceland - Evangelical Lutheran; USA - Protestant and Roman Catholic (only about one-sixth of religious adherents are not Christian); Japan, New Zealand - Roman Catholic, Anglican, and Presbyterian. All the data are derived from Encyclopaedia Britannica(http://www. britannica.com). 
countries and - what is even more important - Christian societies, are ready to take Christ's teaching about old people and face the aging as a global process and challenge for them. To meet above - mentioned target we will look through a wide range of written sources starting from the universal - for all Christians - teaching of the Holy Bible, going through the official standpoints of different Christian denominations and finally looking at the real everyday life and day - to - day routine in one of the Christian countries presented by daily press.

Such approach will lead us to division of the paper into three parts. In the first part we will analyse the Holy Bible. In the second one we will present the standpoints of different Christian denominations derived from sources intentionally chosen to concisely show religions' approach to the aging. In the third part we will analyse all available sources referring to low regulations, social services for old people and a social attitude towards aging and helping old people in Poland one of so called "Christian countries".

\section{CHRISTIANITY AND CHRIST'S TEACHING ABOUT OLD PEOPLE}

According to the Encyclopaedia Britannica Christianity is a:

"major religion, stemming from the life, teachings, and death of Jesus of Nazareth (the Christ, or the Anointed One of God) in the 1st century AD. It has become the largest of the world's religions. (...) Its largest groups are the Roman Catholic Church, the Eastern Orthodox churches, and the Protestant churches; in addition to these churches there are several independent churches of Eastern Christianity as well as numerous sects throughout the world. (...) As a tradition, Christianity is more than a system of religious belief. It also has generated a culture, a set of ideas and ways of life, practices, and artefacts that have been handed down from generation to generation since Jesus first became the object of faith. Christianity is thus both a living tradition of faith and the culture that the faith leaves behind" (http://www.britannica.com/EBchecked/topic/115240/Christianity).

Christian doctrine about old age and attitudes towards old people goes back to the Old Testament which is full of examples of long lives and long lived patriarchs. Most of these lives are good and happy and rather negate the common belief that old age is not the best thing created by God. A good example is Abraham's long life. "Abraham lived a hundred and seventy-five years. Then Abraham breathed his last and died at a good old age, an old man and full of years; and he was gathered to his people" (Genesis 25:7-8, NIV).

The most important teaching concerning the attitude towards old people can be found in Ten Commandments (Decalogue). The Ten Commandments appear twice in the Hebrew Bible, first in Exodus 20:1-17, and then in Deuteronomy 5:4-21 they read as follows: "Honour your father and your mother, so that you may live long in the land the Lord your God is giving you " (Exodus 20:12) and "Honour your father and your mother, as the LORD your God has commanded you, so that you may live long and that it may go well with you in the land the LORD your God is giving you" (Deuteronomy 5:16). As all the Commandments these are conside- 
red to apply to adults so "mother" and "father" ought to be rather elderly people. It is worth admitting that the fifth ${ }^{17}$ Commandment is the only one promising some kind of "reward" for observing it. Actually, the reward promised to people respecting their elderly parents is long life itself. It leads us to - widely present in Old Testament - understanding an old age as some kind of blessing.

The meaning of the fifth/fourth commandment explains Małgorzata Strzelec (2008) referring to John Paul II teaching:

"It is not limited to respect and honour for parents, but includes all elderly people. As the Pope underlines, the importance of this commandment is proved by its position on the very top of the second tablet of Decalogue. This tablet includes the commandments referring to one's acts towards himself and other people. John Paul II underlines that wherever this commandment is observed, old people do not have to be afraid of being recognized as useless or difficult. They would not have to live with a conviction of being a burden for somebody" (p. 183).

As mentioned above, it is important to remember that in biblical times people rarely lived to their eighties or nineties. And the unusually long life of biblical patriarchs from The Book of Genesis ${ }^{18}$ is usually treated as the life of their whole dynasties. As Piotr Ostański explains this biblical fact: "particular biblical persons are actually personifications of whole houses or gens" (Ostański, 2007, p. 230). Actually, after long lives of Adam's family line God decided to limit the man's life to 120 years: Then the Lord said, "My Spirit will not contend with humans forever, for they are mortal; their days will be a hundred and twenty years" (Genesis 6:3, NIV). This is quite long even for modern standards.

Christ's teaching about old age and old people, presented in New Testament, is clear and simple. As P. Ostański wrote "it is related to three questions: material aid for widows, help for elderly parents and regard for parents" (Ostański, 2007, p. 591). The most important recommendation left by Jesus to his followers is the commandment of love and it applies to all people, including the old ones. Christ says: "Love your neighbor as yourself" (Mat 22:39, NIV). And from there Christianity derives all other moral hints concerning attitude towards old people. As Joan Carrera i Carrera ${ }^{19}$ (2007), specialist in moral theology writes:

"Christian ethics, based on faith in God the Father (and His Holy Mother), makes the rest of humanity into our "brothers-sisters" and on a social level, this belief should aid to the construction of a society that is based on a solidarity" ( $p$. 30).

17 Roman Catholics teaching and tradition (Catechism of the Catholic Church) and Luther's Large Catechism (accepted by Lutherans) generally follows Augustine and numbers the particular commandment as fourth.

18 For example: Altogether, Adam lived a total of 930 years, and then he died. (Genesis 5:5), Altogether, Jared lived a total of 962 years, and then he died. (Genesis 5:20), Noah lived a total of 950 years, and then he died. (Genesis 9:29), When Eber had lived 34 years, he became the father of Peleg. And after he became the father of Peleg, Eber lived 430 years and had other sons and daughters. (Genesis 11:16-17).

19 Dr Carrera i Carrera is Spanish. Spain is recognised as one of more Catholic countries in Europe. According to Encyclopaedia Britannica there is no official religion in Spain but "vast majority of the population is Roman Catholic" (http://www.britannica.com/place/Spain/ Castilian\#toc70279). 
As the Holy Bible is the main source of Christian teaching regarding beliefs, practices, traditions and morals, we can find most of the instructions for proper life in the biblical books of Old and New Testament. Thus, in St. Paul Letter to Timothy we read:

"Do not rebuke an older man harshly, but exhort him as if he were your father. Treat younger men as brothers, older women as mothers, and younger women as sisters, with absolute purity. Give proper recognition to those widows who are really in need. But if a widow has children or grandchildren, these should learn first of all to put their religion into practice by caring for their own family and so repaying their parents and grandparents, for this is pleasing to God. The widow who is really in need and left all alone puts her hope in God and continues night and day to pray and to ask God for help" (1 Timothy 5:1-5).

\section{THE ROLE OF FAMILY IN TAKING CARE OF OLD PEOPLE}

Although the commandment of love relates to all people, and fifth/fourth commandment - to all elderly people, we still love more and take more care of the members of our families. So, it looks as though the churches' problem with ageing of the population is not only connected with the growing number of old people, but also with the changing role and structure of the Christian family in the so called developed countries. Marian Machinek (2011) writes on this phenomena:

"The change in family structure is seen mainly in a decreasing number of family members. It means not only a deceasing of number of children. The multigeneration families which used to give an area for wide interpersonal interactions not only for parents and their children, but also for aging grandparents, not mentioning a number of lonely uncles and aunts (...) were replaced by families narrowed to parents and children" (p. 14-15).

Why is the changing family system important regarding the old people situation? As Joanna Kluczyńska ${ }^{20}$ wrote: "the most important social support system for any individual should be the family environment and - in the next step a local environment in which the family is living" (Kluczyńska, 2014). One of these local environments is the church community. If these environments and communities are Christian, the cultural and religious rules derived from Christ's teaching should not only be known to everyone but also observed. In her article about caregiving activities of churches J. Kluczyńska points out the differences in motivation between secular NGOs and churches starting caregiving and helping the seniors. In NGOs activities the motivations can be different: from a way of free time spending (voluntary work), through humanitarianism ending with fulfilling Christ's teaching. The latter should be the main source of motivation for churches activities, as "helping the needy is an integral part of Church service both as an institution and as personal engagement of its members " (Kluczyńska, 2014).

20 It is important to notice that Joanna Kluczyńska is a Polish protestant theologian and social worker, she also holds a PhD in pedagogy. 
The family support is nothing exclusively Polish. As Susanne S. Paul and John A. Paul (1994) admit:

"Governments continue to promote "family support" as a viable option to pensions. Government ministers from Argentina to Zambia have called on families to step in and give succour to their old members in times of pension cutbacks. Governments and conservative analysts have even argued that family support is better than pensions, claiming that it re-enforce family unity and solidarity" (p. 74).

Different denominations teaching concerning attitude towards old people

As all the Christian denominations have their belief sources in the Old and New Testaments, differences between the churches should not be very big. Notwithstanding this we will try to look at Catholic, Orthodox and Protestant teaching and practice separately.

\section{ROMAN CATHOLICS}

Apart from the teaching of the Holy Bible and the Holy Tradition, for the Roman Catholic Church the teaching of the Pope, the Bishop of Rome as a successor to Saint Peter is very important ${ }^{21}$. Therefore in Catholic doctrine one of the signs that old age and elderly people should be considered churches' object of interests are the documents written by Popes, among them the Letter to the Elderly written by Pope John Paul II ${ }^{22}$. On other John Paul's II documents about elderly people and old age M. Strzelec in her "Needs of people advanced in years in teaching of John Paul II" (Strzelec, 2008) writes:

“The letter was written not only in the UN's year devoted to old people (1999) but also in 79th year of John Paul's life. The Pope began his letter with an extract from Psalm 90 and then admitted that in biblical times people had rarely lived till their seventies." life:

Further the author presented some of biblical examples of old people and long

"Indeed, in the word of God, old age is so highly esteemed that long life is seen as a sign of divine favour (cf. Gen 11:10-32). In the case of Abraham, in whom the privilege of old age is stressed, this favour takes the form of a promise (...). At Abraham's side is Sarah, a woman who sees her body growing old, yet experiences within the limitations of her aging flesh the power of God who makes good every human shortcoming. Moses too was an old man when God entrusted him with the mission of leading the Chosen People out of Egypt. It was not in his youth but in his old age that, at the Lord's command, he did mighty deeds on behalf of

21 " the Roman Pontiff, when he speaks ex cathedra, that is, when carrying out the duty of the pastor and teacher of all Christians by his supreme apostolic authority he defines a doctrine of faith or morals to be held by the universal Church" (Vatican Council I, 1869-1870, First dogmatic constitution on the Church of Christ Pastor Aeternus (http://catholicplanet.org/councils/20Pastor-Aeternus.htm).

22 Beside mentioned above regulation of dogmatic constitution, teaching of Johan Paul II is specially considered in this article for two reasons: 1. the Pope himself was Polish, 2. he himself lived to be 85 years old. 
Israel. (...) There is also Eleazar, whose martyrdom bore witness to an exceptional generosity and strength (cf. 2 Macc 6:18-31)" (John Paul II, 1999).

Then the Pope presented some examples of old people from New Testament:

"The Gospel of Luke begins by introducing a married couple "advanced in years" (1:7): Elizabeth and Zechariah, the parents of John the Baptist. (...) In the Temple at Jerusalem, Mary and Joseph bring Jesus to offer him to the Lord (...) There they meet the aged Simeon. At Simeon's side we find Anna, a widow of eighty-four, a frequent visitor to the Temple, who now has the joy of seeing Jesus. (...) Nicodemus too, a highly-regarded member of the Sanhedrin, was an elderly man"(John Paul II, 1999).

Going back to the Old Testament the author recapitulated the biblical view on old age, he quoted Psalm 92 and then wrote:

"Thus the teaching and language of the Bible present old age as a "favourable time" for bringing life to its fulfilment and, in God's plan for each person, as a time when everything comes together and enables us better to grasp life's meaning and to attain "wisdom of heart". "An honourable old age comes not with the passing of time", observes the Book of Wisdom, "nor can it be measured in terms of years; rather, understanding is the hoary crown for men, and an unsullied life, the attainment of old age" (4:8-9). Old age is the final stage of human maturity and a sign of God's blessing" (John Paul II, 1999).

In his Letter to Elderly John Paul II also explained what it means to "honour your father and your mother": "Honouring older people involves a threefold duty: welcoming them, helping them and making good use of their qualities. In many places this happens almost spontaneously, as the result of long-standing custom" (John Paul II, 1999).

Regarding the ways of supporting seniors, the Pope, who was Polish himself, who was brought up in the Polish culture and the Polish way of thinking and who affected Polish way of thinking and acting in a very strong way, wrote:

"The most natural place to spend one's old age continues to be the environment in which one feels most "at home", among family members, acquaintances and friends, where one can still make oneself useful ${ }^{23}$. As the number of older people increases, keeping pace with the rise in average life expectancy, it will become more and more important to promote a widespread attitude of acceptance and appreciation of the elderly, and not relegate them to the fringes. The ideal is still for the elderly to remain within the family, with the guarantee of effective social assistance for the greater needs which age or illness entail. On the other hand, there are situations where circumstances suggest or demand that they be admitted to "homes for the elderly" where they can enjoy the company of others and receive specialized care. Such institutions are indeed praiseworthy, and experience shows that they can provide a valuable service when they are inspired not only by organizational efficiency but also by loving concern. Everything becomes easier when each elderly resident is helped by family, friends and parish communities to feel loved and still useful to society" (Johan Paul II, 1999).

23 We will see similar way of thinking and read similar words in writings of mentioned below Orthodox hierarch of Russian origins. 
Although all the statements from the Pope's Letter to Elderly are widely known and not new the document itself is rather unique. As other Christian churches have quite different structure and do not have the so called "worldwide leader", we will not find similar papers in other Christian denominations. But it does not mean that the representatives of other Christian churches do not speak about attitude toward old people on behalf of their churches and do not give any recommendations about acting towards them.

\section{ORTHODOX CHURCH}

On behalf of Orthodox church Metropolitan Anthony of Sourozh gave a speech to the Christian Council on Ageing titled "The Spirituality Of Old Age", which was later published by the Council as Occasional Paper 4. In his paper Metropolitan Anthony underlined both the situation of taking care of old people by their families and friends and the difficulties of receiving the care by the elderly people themselves. He wrote:

"as we grow old we may well become dependent because we see badly or because we lose our mind or because we are physically handicapped or because we are seriously ill. And so often old people say: „Why don't I die? I don't want to be a burden to others!" (...) But you are never a burden if (and there are two 'ifs'). If people love you, you are not a burden. They have the joy and privilege of looking with tenderness, concern and intelligence at someone whom they have loved all their lives; and though the word is perhaps ugly, the opportunity to repay all that this person has done. (...) But not unconditionally; and this is the second if ! If you are an elderly person who has become dependent on the tenderness, the love and faithfulness of those around you, you must make it easy and possible for them. You must learn to accept what you are given graciously and to make of the relationship of giving and taking a feast and not a calamity for both of you. And you know, to be able to receive graciously, gratefully, joyfully is an art which we do not always possess. (...) To accept the gift with joy, with open heartedness, with shining eyes, giving tenderness in response to tenderness is not only the best, but the only way of making the giving as easy as possible. (...) It is a schooling we must give to other people when they are ageing, and a school we must go through ourselves as soon as possible, because we all depend on one another's love (...) We must learn at all ages how to receive with gratitude, to receive with grace, to receive in such a way that the giving should be a joy for the giver and add new depth to the relationship" (Bloom, 1985).

Metropolitan Anthony of Sourozh gave a speech on ageing also at the Gerontology Conference in 1999. He himself was 85 years old at this time and he strongly underlined the social aspect of ageing: "Ageing hits people nowadays earlier in a sense than it did in the past, because in the past it is the run of time that made people aged, now it is social circumstances" (Bloom, 1999). He recalled the biblical teaching about the old age and pointed out present day change in this area: "So that in a certain sense one can not turn to people of the older generation for 
guidance but one can turn to them for wisdom and humility if they are capable of the one and of the other" (Bloom, 1999). He underlined again the giving - receiving relationship between the family and friends of and old person and the person himself/herself.

Metropolitan Anthony (Bloom) also referred to the stereotypical differences between East and West regarding caring about elder family members and friends. While in the West it is very common to send old people to residential homes or find for them paid caregivers in the East (including Poland) it is treated as a subhuman behaviour and a lack of gratitude for older generations. This difference can be seen in the opposition of physical comfort and safety of an old person and its family versus the mutual psychical safety and good relationship between them. Metropolitan Anthony of Sourozh explains this in following way:

"This is what makes us, Russians, so terrified at the thought of our old people being sent into old people's home to age with comfort and die in loneliness. We prefer to give them a difficult end of life because we haven't got the means to give them physical comfort but we have the means of being there and allowing them not only to receive from us all we can give - and at times it's infinitely little, but give us a smile of gratitude, a warm word of affection, show that nothing can separate us. This is what I would call the spiritual dimension in the relationship" (Bloom, 1999).

Although it is not said directly in the two above mentioned speeches of one of the Orthodox hierarchs, we can see that the Orthodox church takes it for granted that the families and friends should take care of their elders and that they should treat this necessity not as an obligation but a privilege.

\section{PROTESTANTISM}

As Protestantism is so divided internally into many different churches we will present first only some aspects and some protestants' points of view. First of all we have to present some Luther's ideas about the commandment of love and rising from this commandment obligation for charity and help. Mikołaj Jacek Łuczak presenting religious implication for understanding the idea of charity wrote about Protestantism: "Luther denied salutary performing charity and other good acts (...) and he taught that the proper benefits should be a disinterested sign of God's and fellow being's love" (Reinhard, 2009 as quoted in Łuczak, 2014, p. 19-20). He explained also that Luther "did not shatter in this way the Evangelical idea of charity itself, nor the religious obligation to act good as they are results of neighbours' loving" (Euczak, 2014, p. 19-20).

And of course Luther's idea of charity does not deny the obligations of honouring seniors, loving other people and helping the needy. Béla Harmati, the editor of the booklet regarding the study program on Christian ethics and prepared by The Lutheran World Federation, reminds that: "According to the Scriptures, property must be shared with others. We are not only bound to God as stewards, we are at the same time everyone's neighbours" (Harmati 1982, p.11). This quotation 
does not say anything directly about seniors, but reminds us about our relations with other people. So we can assume that it is said regarding elderly people as well. But on the web sites of protestant charity organizations (http://protestantaid.org/, http://www.diakonia.org.pl/, http://www.diakonia.pl/, http:// www.lutherancharities.org) from different countries we can see that one of the areas of their interests are seniors and their needs.

It is important to underline that some legal acts regarding the relationships between Poland and some of protestant churches (like Seventh Day Adventist Church and Baptist Church) among various regulations in charity area have some paragraphs regarding propagating the idea of loving fellow creatures (our brothers and sisters in God) and helping them as well as promoting and popularising these attitudes towards people (http://isap.sejm.gov.pl/ DetailsServlet?id=WDU19950970480).

The teaching of the Holy Bible and of all the denominations that was presented above is a splendid theoretical approach to the ageing problem from the Christian point of view. Now it is time for presenting the practise. Although the theory is almost the same all over the world, the practice will differ but will have some common aspects.

Limiting the area of our interest in this part of the paper and choosing only one from the Christian countries, in this article we would focus especially on Poland for the reasons mentioned below:

1. Poland is the home country of the article's author. It means that the situation of the country and old people's circumstances are better known to the author than those in any other country;

2. Poland is the country where $88,84 \%$ of population declare to be Christians;

3. Poland is the country that was ranked in the second half of the table of ranked countries and one of the lowest ranked Christian ones;

4. The publications, of Polish sources on this subject of Polish origins are very seldom - if at all - translated into other languages and not known outside Polish speaking readers.

\section{CHRISTIANITY AND THE PRACTICE OF CAREGIVING. CHRISTIAN CAREGIVING FOR SENIORS IN POLAND}

Nowadays Christianity, like the rest of the world, is somehow interested in old age and ageing but it usually treats old age only as preparing for death. More and more books written by priests of all the denominations are published. Quite often their authors quickly leave the subjects of old age and ageing and go straight into the subject of death (and preparing for it) and eternal life. It is also interesting to mention that the authors of books on social work or caregiving very seldom raise the subject of caring about old people. They are more interested in children, unemployed or sick people. But as it was mentioned above Poland is a Christian country and it effects many different fields of life in Poland including attitudes to other human beings (seniors as well). In Poland these religious obligations 
mentioned in previous passages of the paper seem to be very deeply rooted in the tradition and even the law regulations regarding the seniors and family's duties towards them.

Social security regarding ageing people in most European countries (including Poland) covers the pensions - the money regularly paid to people over prescribed age. More conditions which one has to fulfil to receive pension are specified in the particular country's law regulations. The regulations state also other benefits that old people can receive. It is worth to underline that, as the authors of Humanity comes of age. The New Context for Ministry with the Elderly wrote, starting from 1940s some efforts had been made to raise the issue of old people's rights in the UN. What is both interesting and sad, it had always been blocked by governments, even of the so - called Christian countries: "governments put old age on the back burner and steadily blocked any special international mechanisms to protect or empower the elderly" (Paul, Paul, 1994, p. 128).

Some legal aspects of charity work and supporting elderly people in Poland are included in Social Service Act of 2004 (http:/ / isap.sejm.gov.pl/DetailsServlet?id=WDU20040640593), Guarantee of Conscience and Confession Freedom Act of 1989 (http://isap.sejm.gov.pl/DetailsServlet?id=WDU20040640593), Act of Public Good Activity and Volunteering of 2003 (http:/ / isap.sejm.gov.pl/DetailsServlet?id=WDU20030960873). According to the Polish Social Service Act: "Social service is organized by public administration and local government authorities which cooperate in this field with social and nongovernment organizations, the Catholic Church, other churches, faith communities and bodies corporate and natural legal persons." But Christianity it is not only a "system of religious beliefs" followed in different Churches as organizations. It is first of all the way of living, including the way of family life. From this understanding of Christianity we can draw the conclusion, that the law requiring financial help for the parents experiencing poverty is very Christian.

Also the Guarantee of Conscience and Confession Freedom Act among the possible activities of churches and faith communities specifies the caregiving and charity acts. These kinds of activities held by churches is regulated by some articles of different Acts arranging the relationships between Poland and different churches $^{24}$. Also the Act of Public Good Activity and Volunteering specify some activities to be held by the Catholic Church, other churches and faith communities. Among them we can find the "activities towards people of pensionable age" which also includes pursuing the residential homes.

It means that not only the Bible's and the churches' teaching but also the law regulations in some ways force some behaviour towards old people.

S. S. Paul and J. A. Paul write about all these aspects:

"The Ministry with senior citizens is formed in a community and covenant context. The church's ministry is not a patronizing act, but rather a call to work with our brothers and sisters who are aged. We are interdependently linked in the

24 There are many different acts and they regulate relationships between particular churches and the state. They have also different regulations concerning churches activities in the area of charity although they all do have such regulations in this area in more or less extended form. 
life-affirming process of aging. As the way of Christ we participate in the aging process. We become stewards who are called to bring justice in relationships, promote peace, and affirm the integrity of creation, further enhancing the future of our planet and the next generation" (Paul, Paul, 1994, p. 141).

Going back to the old people's situation in Poland it is worth remembering and underlining that during National General Census in 2011 88,84\% of Polish population declared affiliation to one of the Christian churches (http:/ / stat.gov. pl/spisy-powszechne/nsp-2011/nsp-2011-wyniki/wybrane-tablice-dotyczaceprzynaleznosci-narodowo-etnicznej-jezyka-i-wyznania-nsp-2011,8,1.html) and that most Poles are Roman Catholics. It may somehow impact on the attitude toward old people in Poland. As Poland is a catholic country most people tend to believe in obeying the Commandments and churches' teaching. It is usually believed that the best care can be given by family members, especially the women daughters, daughters-in-law, granddaughters. Bishop K. Romaniuk writes about the role of the family in seniors' life and its role in supporting them: "Christian parents starting their independent life with their own children, should be interested if not in living with ageing grandparents under one roof, then in frequent contacts at least" (Romaniuk, 1993, p. 82).

But along with population ageing comes the big change in style of family life. As Justyna Deręgowska (2008) points out:

"The conviction about the family crisis which struck old people is widely spread. Limitation of family importance as a basic social environment, main source of social help (...) and the most important referred group ended up in changes in many aspects of one's life. (...) Social values concentrated around respect of old age, old people's rights, their wisdom and experiences have changed. During our lifetime the natural system of care and support for elderly or dying people - the family, has begun to vanish. Suffering and illnesses of old people have become a problem for the family. Very often ignored. (...) Until recently (...) the situation of an elderly person in the family was seen as more favourable. Binding social norms and socially legitimized moral demand for taking care of old family members, used to oblige the children to care for and support their parents and grandparents. There was a stereotypical conviction that the family should take care of its seniors. Nowadays (...) more and more often the family does not take any supporting activities towards them. The consequence of all social changes is the inclination to institutional care towards old, sick and dying people" (p. 191).

J. Deręgowska points out that in Poland there is a very strong social pressure on family members concerning caring for their elderly. But she also emphasis that this subject is enclosed somewhere between a taboo and unspoken guilt. This point of view is shared by other authors as well:

"Poles still have a very deeply rooted conviction that supporting an old person is a family duty. Even village authorities asked in a survey by Institute of Public Affairs, took it for granted; why should they organize any kind of supporting systems if the seniors' place is at home, with the family? Actually with one family member, usually a daughter. (...) These modern daughters are called the sandwich generation by western sociologists; on the one hand there are growing children 
expecting support, on the other hand - ageing parents. So they are sandwiched between them and being eaten alive like a sandwich" (Bunda,Walewski, 2012).

In an article published in August 2013 Ewa Wilk asked what do we owe to our old parents? As she wrote in the article, taking care of elderly parents is becoming more and more a sphere of a social taboo and twinge of guilt. The author quotes the $\mathrm{CBOS}^{25}$ survey results ${ }^{26}$ according to which $50 \%$ of Poles consider putting their parents into a residential home censurable as much as children's biting or infidelity. According to results quoted only $10 \%$ are ready to excuse such acts in an extraordinary situation. In Poland, if we are not able to take care of old family members ourselves, we prefer to hire an Ukrainian women to take care of our grandparents or old parents. Correspondingly Polish women work as carers in Germany, Italy or Great Britain. Quite a lot of such work offers can be found in the Internet, newspapers or even on street billboards. This kind of help is seen to be more humane than a residential home Sooner or later almost all seniors would need some kind of help and support. One of the authors looking at old age from the biblical point of view, priest Piotr Ostański, in his "Biblical Perspective of Old Age" explains the aim of seniors' need for help from God's point of view : "dependency on other people's support is a difficult lesson of humility and ability to receive the help" (Ostański, 2008, p. 126).

This problem is seen not only by scientists and church activists but also by some careful observers of everyday life like some of the Polish writers. A former journalist and an author of the novel "Dearest" Wanda Żółcińska said in an interview: "It is difficult for us to get into the role of a caregiver for our ageing parents" (Nowakowska, http://weekend.gazeta.pl/weekend/1,138589,17461505,_Ciezko_nam_wejsc_w_role_opiekuna_naszych_starzejacych.html). Further she added:

"Now the average life expectancy is getting longer and the status of old people will change. Certainly someone will try to make money on them. Or rather on us - on our feeling of duty. There will be luxury facilities to which we will be able to hand over the care. We would have "only" to work for this" (http:/ / weekend. gazeta.pl/weekend/1,138589,17461505,_Ciezko_nam_wejsc_w_role_opiekuna_ naszych_starzejacych.html).

\section{OUTSIDE THE CHRISTIAN WORLD}

As M.J. Łuczak (2014) reminds:

"A postulate or even demand for charity lays in the background of European culture and is present in Judaism, Christianity and Islam. Looking at charity as an act that is aimed at improving the life situation of other people which is followed by caring about their dignity, freedom and happiness, we can find its implications also in the philosophy of humanism" (p. 10 - 11).

Judaism shares the Old Testament and the Ten Commandments with Christianity. It means that Judaism also demands respect and support for seniors ${ }^{27}$. More-

25 Centre for Public Opinion Research

26 The author does not give any information about the date of the survey or any other directions that could help the reader to identify the survey which is quoted or find the source of it.

27 After bar micwa (for boys at the age of 13) and bat micwa (for girls at the age of 12) the boys 
over, it also requires charity. But unlike Christianity it does not oblige the people to any charity acts towards strangers. Judaism is more ethnic and tribal and limits its demands of support to brothers of the nation.

Looking more widely, beyond the Christian world, we can recognize the situation of old people in Europe or North America - even the old people in residential homes - very satisfying and rather safe. During the last few years the news from India about killing old parents has been published in newspapers all around the word. It is said that the ritual of "thalaikoothal" - killing old family members, had existed for ages but was discovered only in 2010.

"Some call it euthanasia," said Rajeshwar Devarakonda, social protection head at HelpAge India, a civic group focused on elderly care. "Others call it homicide." Although it can take various forms, a common approach is that once an elderly relative becomes seriously ill and the family can't afford to care for the person, a date is set. (...) The victim is given an oil bath, a head massage perhaps involving cold water and an exceedingly large amount of green coconut milk, leading to death. (...)Thalaikoothal - traditionally for those 50 and older who become incapacitated, although younger people who become very ill are also targeted - is as natural as a birthday or wedding, some say" (Magnier, 2013).

Although the Christians may not understand it, in a world without Old Testament's commitments and Christ's teaching of love, the above mentioned practice is treated as normal and understandable and the family acts are being excused even by potential victims themselves (http://archive.tehelka.com/story_main47. asp?filename $=$ Ne201110Maariyamma.asp).

\section{CONCLUSION}

As pointed out above the Christian teaching and theoretical approach to the aging is unfortunately very different from practical approach. And even if legal regulations and teaching of Christian churches' themselves demand honouring, helping and caregiving for old people, the action towards seniors took by Christian communities and Christian societies especially are less observed.

Among the reasons for writing their book S. S. Paul and J. A. Paul mentioned some important questions, like: "why the World Bank has pressed for health-care reforms that cut off services for older people; and why families everywhere assume less and less responsibility for older parents." (Paul, Paul, p. x). Although the authors write about the part of the world that they call "South" - from Caribbean and Latin America, through Africa and ending in the south of Asia - many observations about seniors situations are true everywhere in the world. And this may be the reason why the authors become so critical and demanding in their judgment about the role of Christian churches and Christianity in general. ${ }^{28} \mathrm{Cited}$

and girls are not treated any more as children and they are obliged to meet the requirements of Halakha on their own responsibility.

28 They write for example: "All too often, gerontologists, doctors, social workers and welfare bureaucrats claim to speak in the name of older people. Church leaders do the same." (Paul, Paul, 1994, p. 134); "churches need to attend to the body as well as the soul; they must join in 
above M. J. Łuczak quotes also the work of Alfred Klose and his statement that "charity actions and all kind of efforts in favour of giving help are the sign of Christian solidarity" (Klose, 2003, p. 15 as quoted in Łuczak, p. 13). To make this conclusion more complete and going beyond the charity and some material support for old people, we could add one more important statement from the paper by Elżbieta Osewska: "significant challenge for Christian communities is aspiration for active inclusion of seniors into communities' life and not leaving them lonely." (Osewska, 2013, p. 20)

\section{REFERENCES}

Bloom A. (1985). The Spirituality of Ageing . Retrieved from http://masarchive.org/Sites/ texts/1985-00-00-0-E-E-T-EM05-001SpiritualityOfOldAge.html

Bloom A. (1999). Gerontology Conference in Bournemouth. Retrieved from http:/ / masarchive.org/Sites/ texts/1999-09-17-1-E-E-T-EM06-017GerontologyConference.html

Benz E.W. (n.d.). Christianity. Retrieved July 20, 2015 from http://www.britannica.com/topic/ Christianity

Bunda M., Walewski P. (2012). Starość: problem młodych [Old Age: the Problem of Young People]. Retrieved from http://www.polityka.pl/tygodnikpolityka/spoleczenstwo/1529755,3,kto-masie-zajac-opieka-nad-polskimi-seniorami.read

Carrera I. \& Carrera J. (2007). Identities for the 21 century. Barcelona: Christianisme i Justicia Booklets.

Charitable Services (n.d.). Retrieved August 1, 2015 from http:/ / protestantaid.org/charitable-services

Dręgowska J. (2008). Postrzeganie starości i odchodzenia we współczesnym świecie [Percepcion of Old Age and Passing Away in the Temporary World]. In: R. Konieczna - Woźniak (Ed.), Dorostość wobec starości. Oczekiwania - Radości - Dylematy [Adulthood towards the Old Age. Expectations Joys - Dilemmas] (pp. 187 - 194). Poznań: Adam Mickiewicz University Press.

Ekumeniczna Stacja Opieki [Ecumenical Care Station]. Retrieved August 2, 2015 from http:/ / www.diakonia.pl/

First Dogmatic Constitution On The Church Of Christ Pastor Aeternus (n.d.). Retrieved August 10, 2015 from http://catholicplanet.org/councils/20-Pastor-Aeternus.htm

Global AgeWatch Index 2014: Insight report, summary and methodology. Retrieved February 10, 2015 from http://www.helpage.org/global-agewatch/

Harmati B. (1982). Some introductory notes on the study program on Christian ethics and the question of property. In: B. Harmati (Ed.), Christian ethics and the question of property, (pp. 7 - 13). Geneva: Department of Studies The Lutheran World Federation.

Johan Paul II (1999). Letter OfHis Holiness Pope John Paul II To The Elderly. Retrieved fromhttp:/ / w2.vatican. va/content/john-paul-ii/en/letters/1999/documents/hf_jp-ii_let_01101999_elderly.html

Kluczyńska J. (2014). Praca socjalna a działalność pomocowa Kościołów - cechy wspólne, różnice, inspiracje [Social Work and an Assistance Activity of Churches - Common Qualities, Differences, Inspirations]. In: M. Patalon (Ed.), Religijne uwarunkowania pracy socjalnej, [Religious Conditions of Social Work] (p. 76 - 91). Toruń: Wydawnictwo Adam Marszałek.

Konieczna - Woźniak R. (ed.). (2008). Dorostość wobec starości. Oczekiwania - Radości - Dylematy [Adulthood towards the Old Age. Expectations - Joys - Dilemmas]. Poznań: Adam Mickiewicz University Press.

the struggle to develop, strengthen and protect pensions and other income-support programs, as essential security for all people, especially those who are frail or sick." (Paul, Paul, 1994, p. 140); "Far more should be done to create caring health institutions that are responsive not only to physical conditions but also to human beings with individual personalities, life circumstances and values. Churches, with their commitment to the spiritual dimensions of life, are well - placed to bring this emphasis to health services. (Paul, Paul, 1994, p. 140-141); "By learning more about the needs and gifts of the world's elderly, by affirming the full dignity of persons of later life, the churches will discover more completely their own calling" (Paul, Paul, 1994, p. 141). 
Łuczak M. J. (2014). Dobroczynność, wolontariat i praca socjalna - od nakazów religijnych ku profesjonalizacji praktyk społeczno - kulturowych [Charity, Volunteering and Social Work - from Religious Obligations to Professionalizing Socio - cultural Acts]. In: M. Patalon (Ed.) Religijne uwarunkowania pracy socjalnej [Religious Conditions of Social Work](pp. 9 - 30). Toruń: Wydawnictwo Adam Marszałek.

Machinek M. (2011). Ewolucja pojęcia rodziny. Aspekty teologiczno- etyczne [Evolution of the Concept of the Family. Theological and Ethical Aspects] In: P. Morciniec (Ed.), Family Forum, vol. 1. Problemy wspótczesnej rodziny [Problems of Modern Family].Opole: Redakcja Wydawnictw Wydziału Teologicznego Uniwersytetu Opolskiego.

Magnier M. (2013). In southern India, relatives sometimes quietly kill their elders. Retrieved from http:/ / articles.latimes.com/2013/jan/15/world/la-fg-india-mercy-killings-20130116

Na potudniu Indii Na potudniu Indii dzieci zabijaja starych rodziców, topiąc ich w mleku. Dziennikarka walczy $z$ okrutnym rytuatem [In the south of India children kill old parents by drowning them in milk. The journalist fights with cruel rite].(2015). Retrieved from http:/ / wyborcza.pl/1,75477,17356624,Na_ poludniu_Indii_dzieci_zabijaja_starych_rodzicow_html\#ixzz3TCCS3zrP

Nowakowska K. (n.d.). Ciężko nam wejść w rolę opiekuna naszych starzejacych się rodziców. Lęk młodego pokolenia przed odpowiedzialnościa [It is difficult for us to get into the role of a caregiver of our ageing parents. Young generation's fear of responsibility]. Retrieved August 5, 2015 from http://weekend.gazeta.pl/weekend/1,138589,17461505,_Ciezko_nam_wejsc_w_role_opiekuna_naszych_ starzejacych.html

Osewska E. (2013). Wartość życia i cierpienia osoby starszej w perspektywie pedagogiczno - teologicznej [Value of life and suffering of elderly person from pedagogical - theological point of view]. In: J. Stala, N. Bravená (Eds.), Człowiek wobec bólu, cierpienia i śmierci [A human being towards pain, suffering and death] (p. 11 - 22). Kraków: Uniwersytet Papieski Jana Pawła II w Krakowie, Wydawnictwo Naukowe.

Ostański P. (2008). Biblijna perspektywa starości [Biblical perspective of old age]. In: R. Konieczna - Woźniak (Ed.), Dorosłość wobec starości. Oczekiwania - Radości - Dylematy [Adulthood towards the Old Age. Expectations - Joys - Dilemmas] (pp. 121 - 130). Poznań: Adam Mickiewicz University Press.

Ostański P. (2007). Historiozbawcza wizja starości w Piśmie Świętym. Studium egzegetyczno - teologiczne [Historiosalvical View on Old Age in the Bible. An Exegetical - Theological Study]. Poznań: Adam Mickiewicz University.

Paul J. A., Paul S.S.(1994). Humanity comes of age. The New Context for Ministry with the Elderly. Geneva: WCC Publication.

Pomoc osobom starszym (n.d.). Retrieved August 2, 2015 from http://diakonia.org.pl/ komu-i-jak-pomagamy/pomoc-osobom-starszym/

Pomoc społeczna [Social service]. Retrieved August 2, 2015 from http://www.diakonia.pl/

Romaniuk K. (1993). Lata podeszłe i starość według Biblii [Senile years and old age according to the Bible]. Warszawa; Wydawnictwo Sióstr Loretanek.

Shahina K. K. (2010). Mother, shall I put you to sleep? Retrieved from http:/ / archive.tehelka.com/story_ main47.asp?filename=Ne201110Maariyamma.asp

Stala J., Bravená N. (2013). Człowiek wobec bólu, cierpienia i śmierci [A human being towards pain, suffering and death]. Kraków: Uniwersytet Papieski Jana Pawła II w Krakowie, Wydawnictwo Naukowe.

Strzelec M. (2008). Potrzeby osób w podeszłym wielu w nauczaniu Jana Pawła II [Needs of people advanced in years in teaching of Johan Paul II]. In: R. Konieczna - Woźniak (Ed.), Dorostość wobec starości. Oczekiwania - Radości - Dylematy [Adulthood towards the Old Age. Expectations - Joys - Dilemmas] (pp. 175 - 185). Poznań: Adam Mickiewicz University Press.

Sureshpenny Vera Sanso V. (2010). No mercy killing, this. Retrieved from http:/ /www.thehindu.com/ features/magazine/article257994.ece

The Ministries of Lutheran Charities (n.d.). Retrieved August 10, 2015 from http:/ /www.lutherancharities.org/ministries.html

Ustawa z dnia 12 marca 2004 o pomocy społecznej [Social Service Act]. Retrieved August 2, 2015 from http:/ / isap.sejm.gov.pl/DetailsServlet?id=WDU19890290155

Ustawa z dnia 24 kwietnia 2003 r. o działalności pożytku publicznego i o wolontariacie [Act of Public Good Activity and Volunteering]. Retrieved July 13, 2015 from http:/ / isap.sejm.gov.pl/DetailsSe rvlet?id=WDU20030960873 
Ustawa z dnia 30 czerwca 1995 r. o stosunku Państwa do Kościoła Adwentystów Dnia Siódmego w Rzeczypospolitej Polskiej [Act of relationship between the state and the Seventh Day Adventist Church in the Republic of Poland ]. Retrieved August 20, 2015 from http:/ / isap.sejm.gov.pl/Deta ilsServlet?id=WDU19950970481

Ustawa z dnia 30 czerwca 1995 r. o stosunku Państwa do Kościoła Chrześcijan Baptystów w Rzeczypospolitej Polskiej [Act of relationship between the state and the Christian Baptist Church in the Republic of Poland]. Retrieved August 20, 2015 from http://isap.sejm.gov.pl/DetailsServlet?id= WDU19950970480

Wilk E. (2013). Rodzice swoich rodziców [Parents of their parents]. Retrieved from http:/ / www.polityka. $\mathrm{pl} /$ tygodnikpolityka/spoleczenstwo/1553125,2,co-jestesmy-winni-rodzicom.read

Wybrane tablice dotyczące przynależności narodowo-etnicznej, języka i wyznania - NSP 2011 [Selected Tables Concerning National, Ethnics, Language and Confession Affiliation - National General Census 2011]. Retrieved March 3, 2015 from http://stat.gov.pl/spisy-powszechne/nsp-2011/nsp-2011wyniki/wybrane-tablice-dotyczace-przynaleznosci-narodowo-etnicznej-jezyka-i-wyznaniansp-2011,8,1.html 